\title{
Comparative petiole anatomy of cassava (Manihot) species
}

\author{
D. Graciano-Ribeiro ${ }^{1,3}$, D.Y. Hashimoto-Freitas ${ }^{2}$ and N.M.A. Nassar ${ }^{3}$ \\ ${ }^{1}$ Programa de Pós-Graduação em Biodiversidade Vegetal, \\ Instituto de Ciências Biológicas, Universidade Federal de Goiás, \\ Goiânia, GO, Brasil \\ ${ }^{2}$ Departamento de Biologia Celular, Instituto de Biologia, \\ Universidade de Brasília, Brasília, DF, Brasil \\ ${ }^{3}$ Programa de Pós-Graduação em Botânica, Instituto de Biologia, \\ Universidade de Brasília, Brasília, DF, Brasil \\ Corresponding author: N.M.A. Nassar \\ Email: nagibnassar@geneconserve.pro.br \\ Genet. Mol. Res. 15 (1): gmr.15017495 \\ Received August 20, 2015 \\ Accepted January 12, 2016 \\ Published January 22, 2016 \\ DOI http://dx.doi.org/10.4238/gmr.15017495
}

\begin{abstract}
In this study, we describe the petiole anatomy of six wild cassava (Manihot) species, one hybrid, and two cultivars of Manihot esculenta, in order to identify their dominant anatomical patterns and relate them to possible adaptations to abiotic factors in the Cerrado biome. The median parts of several petiole samples were transversally and longitudinally sectioned and stained. The results include data for the taxonomic classification of the genus, including distinctive anatomical characteristics of hybrid varieties of cassava and wild species, such as the presence/ absence of trichomes and a hypodermis, layer type and number in the cortex, number of vascular bundles, cell types in the pith, and type of organization. Morphological analysis revealed differences in length and shape of the petiole insertion. The presence of trichomes, a hypodermis, the amount and type of supporting tissue in the cortex, as well as gelatinous fibers, may be related to drought tolerance.
\end{abstract}

Key words: Cassava breeding; Cerrado biome; Hybrid; Taxonomic key; Wild species 


\section{INTRODUCTION}

Cassava (Manihot spp) is a genus of Euphorbiaceae that is native to South America. It is mainly consumed by low-income people as a staple food source in Africa and the Americas, and includes 99 species (Nassar, 2002). Studies of the vegetative and reproductive anatomical characteristics of Manihot have been conducted in the last decade, and have focused on the stem (Graciano-Ribeiro et al., 2009; Nassar et al., 2008, 2010a,b,c), root (Bomfim et al., 2011a,b), egg cell (Hashimoto-Freitas and Nassar, 2013), and leaves (França et al., 2010). However, knowledge of Manihot petiole anatomy is limited.

Jatropha, which is another Euphorbiaceae genus, has a standard trilacunar petiole, with three to eleven (found in older groups) vascular bundles. The occurrence of only a few bundles is thought to be related to living in cold and arid environments (Deghan, 1982).

Here we describe the petiole anatomy of six wild species, a hybrid, and two cultivars of Manihot, in order to identify the dominant anatomical patterns and relate them to possible adaptation to abiotic factors in Brazilian biomes. In addition, petiole characteristics are useful for investigating the taxonomy of Manihot and its cultivars, when comparing them with hybrids, and relating anatomical features to improve the culture and present an identification key for the taxon.

\section{MATERIAL AND METHODS}

\section{Sampling}

Nine genotypes were studied: six species, two cultivars (UNB 530 and Branca Santa Catarina), and a hybrid between Manihot esculenta Crantz and Manihot glaziovii Müll. Arg. (UNB 110) (Table 1). These materials were collected from the Living Collection of the Biological Station of Universidade de Brasília (UNB), and analysis of the anatomical characteristics of the vegetative structures was conducted at the Plant Anatomy Laboratory, UNB. The groupings considered here represent four of the 18 sections that are based on the morphological criteria of Rogers and Appan (1973), and are as follows: Manihot Mill. (M. esculenta and cultivars), Caerulescentes Roger \& Appan (Manihot caerulescens), Glaziovianae Pax emend. Rogers \& Appan (M. glaziovii and Manihot pseudoglaziovii), and Heterophyllae Pax emend. Rogers \& Appan (M. pohlii).

Table 1. Occurrence in Brazil of the wild Manihot species and cultivars used in the study.

\begin{tabular}{|c|c|c|}
\hline Species & Location (State) ${ }^{1}$ & Reference \\
\hline M. caerulescens Pohl & AM, PA, PI, CE, MA, GO, PE, MT, MG, RJ & (Rogers and Appan, 1973) \\
\hline M. esculenta Crantz, UNB 530 & DF & \\
\hline M. esculenta Crantz, Branca Santa Catarina & DF & \\
\hline M. fortalezensis Nassar, Ribeiro, Bomfim \& Gomes & DF & (Nassar et al., 2011) \\
\hline M. glaziovii Müll.Arg. & $\mathrm{DF}, \mathrm{PB}, \mathrm{PE}, \mathrm{BA}$ & (Rogers and Appan, 1973) \\
\hline M. pohlii Wawra & RJ, ES & (Rogers and Appan, 1973) \\
\hline M. pseudoglaziovii Pax \& K.Hoffm. & $\mathrm{ES}, \mathrm{RN}, \mathrm{PB}$ & (Rogers and Appan, 1973) \\
\hline
\end{tabular}

${ }^{1}$ Brazilian States: Amazonas (AM), Bahia (BA), Ceará (CE), Distrito Federal (DF), Espírito Santo (ES), Goiás (GO), Maranhão (MA), Minas Gerais (MG), Mato Grosso (MT), Pará (PA), Paraíba (PB), Pernambuco (PE), Piauí (PI), Rio de Janeiro (RJ), Rio Grande do Norte (RN). 


\section{Anatomical procedures}

Collection of the plant samples was conducted in early 2013 , and the selected region for study was the middle portion of the petiole. After collection, samples were fixed in $70 \%$ formalinacetic acid-alcohol (Johansen, 1940) for $24 \mathrm{~h}$ and preserved in 70\% ethanol (Berlyn and Miksche, 1976). Histological sections were performed using a microtome table; cuts were made in two directions, transverse and longitudinal, clarified with $20-50 \%$ hypochlorite (Kraus and Arduin, 1997), and stained with alcian blue/safranin-O (4:1) (Luque et al., 1996). After washing, the sections were dehydrated in an ethanol series from $50 \%$ to absolute ethanol, followed by butyl acetate. Slides were mounted using synthetic resin (Paiva et al., 2006). Photomicrographs were taken using an optical microscope (LEICA CM 2500) and processed with the LAS 4.0 software. Petiole measurements from 30 randomly selected samples were taken and the frequency of druses and crystals was noted, which was considered low at fewer than 5 per image and abundant at over 15. Each image corresponded to the view through 10X of the optical microscope.

\section{RESULTS}

Average petiole length varied between the analyzed groups. $M$. caerulescens had the shortest $(6.8 \mathrm{~cm})$ followed by $M$. pohlii $(15 \mathrm{~cm})$, Branca Santa Catarina $(15.8 \mathrm{~cm})$, UNB 530 $(17.6 \mathrm{~cm})$, M. pseudoglaziovii $(24.6 \mathrm{~cm})$, UNB $110(25.4 \mathrm{~cm})$, M. glaziovii $(30.3 \mathrm{~cm})$, and Manihot fortalezensis $(34.3 \mathrm{~cm})$. There were two types of petiole insertion: peltate ( $M$. fortalezensis, $M$. glaziovii, and M. pseudoglaziovii) and basal (the other species) (Figure 1).
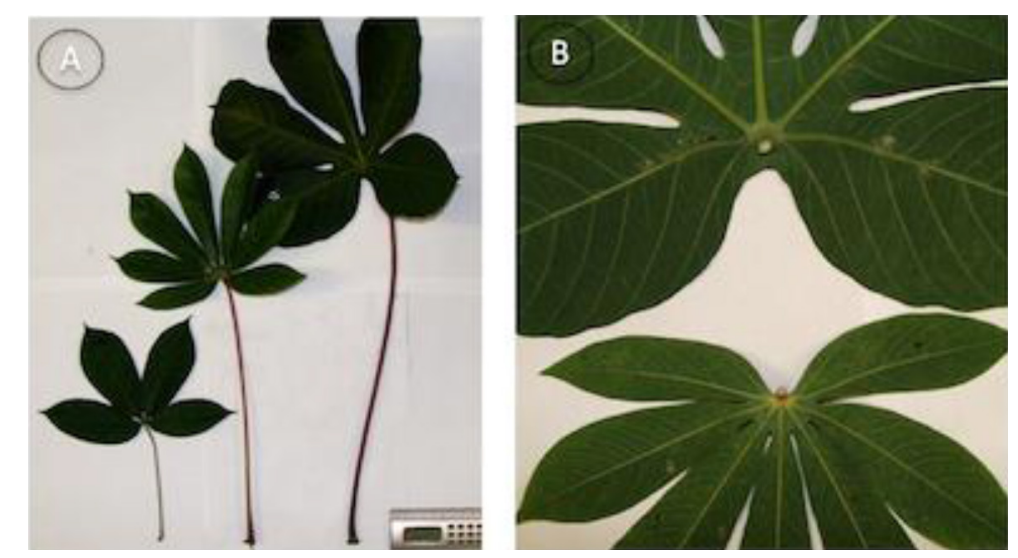

Figure 1. External morphology. A. Petiole and leaf of Manihot pohlii, M. esculenta var. Branca Santa Catarina, and $M$. fortalezensis (left to right). B. Petiole insertion types: peltate (top) and basal (bottom).

The circular margin of the transverse section was similar in all of the species (Figures 2A-B, 3A-B, 4A-B, and 5A-B), and the stele was characterized as an ectophloic siphonostele. The epidermis in transversal sections (Figures 2C-D, 3C-D, 4C-D, and 5C-D) were characterized by a mono-stratified epidermis covered with a smooth and thick cuticle, except in $M$. caerulescens and the hybrid UNB 110, in which it was even thicker. All of the common cells of the epidermis contained anthocyanins and thick walls; a few druses could only be found in UNB 530. Long tector 
trichomes with sharp extremities occurred in M. caerulescens, M. pohlii, and the cultivars UNB 530 and Branca Santa Catarina. In UNB 110, these trichomes were wide. Rare stomata were observed only in M. caerulescens and the cultivars UNB 530 and Branca Santa Catarina. Lenticel formation was recorded in $M$. fortalezensis.

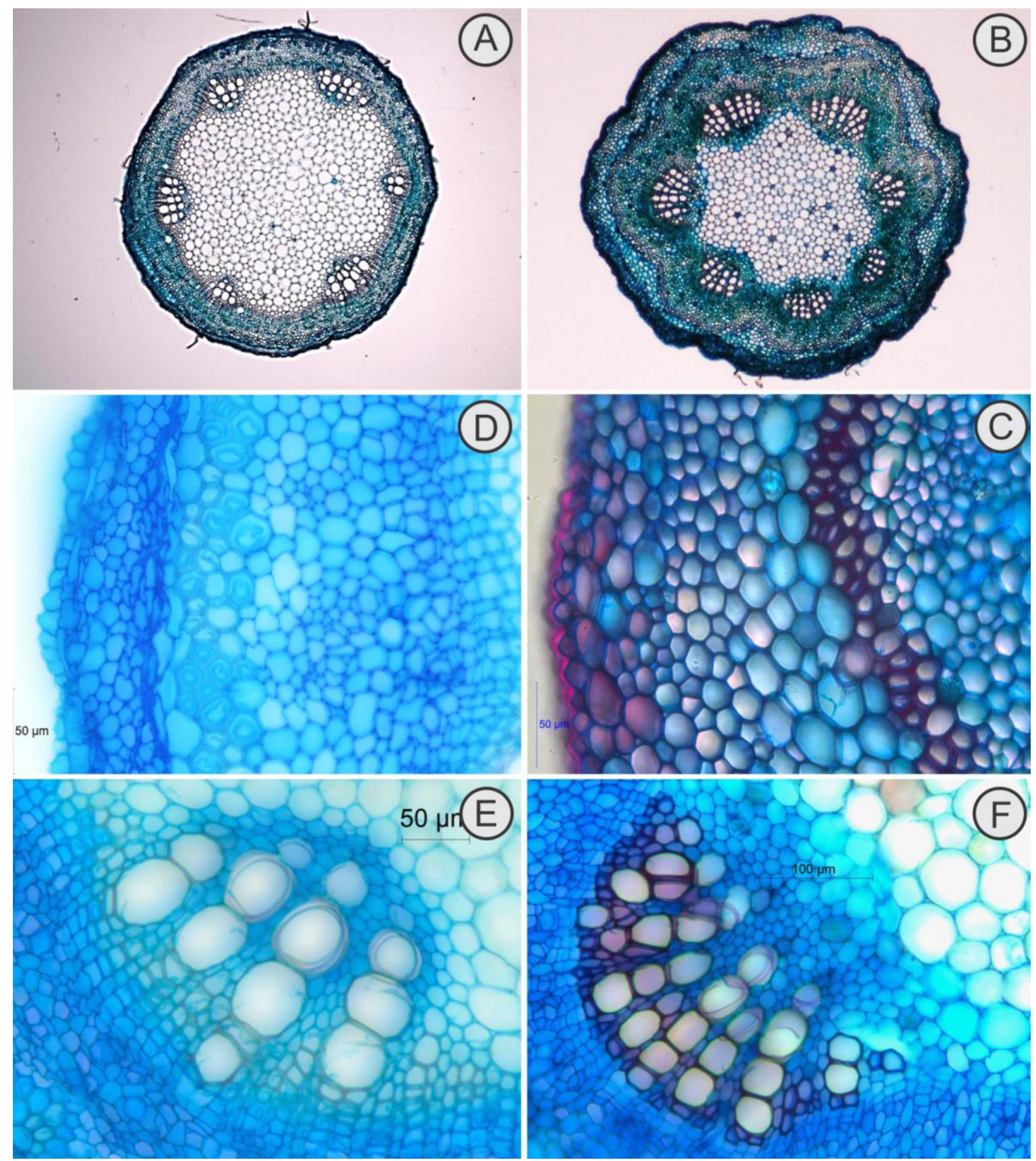

Figure 2. Petiole transversal cross-section. A. B. Overview, number, and arrangement of vascular bundles. C. D. Details of epidermis and cortex with gelatinous fibers. E. F. Details of shape and arrangement of phloem and secondary xylem. A. D. E. Manihot glaziovii; B. C. F. M. pseudoglaziovii. 
In the cortical region of M. pseudoglaziovii, M. glaziovii, M. fortalezensis, and M. pohlii, there was a layer of juxtaposed parenchymal cells that were larger than in the other layers, similar to a hypodermis, followed by chlorenchyma that varied from two layers in UNB 530 to five in the other species. In the cultivar UNB 530, frequent druses and laticifers were found in that region. The collenchyma was angular and the numbers of layers were four in the hybrid, five in UNB 530, Branca Santa Catarina, and M. glaziovii, six in M. pseudoglaziovii, and eight in M. fortalezensis. The internal parenchyma also varied in layer number, from one to three (Branca Santa Catarina and M. pseudoglaziovii) to five to six (UNB 530, M. fortalezensis, and M. glaziovii); these cells were isodiametric and irregularly sized, with druses, crystals, and laticifers.
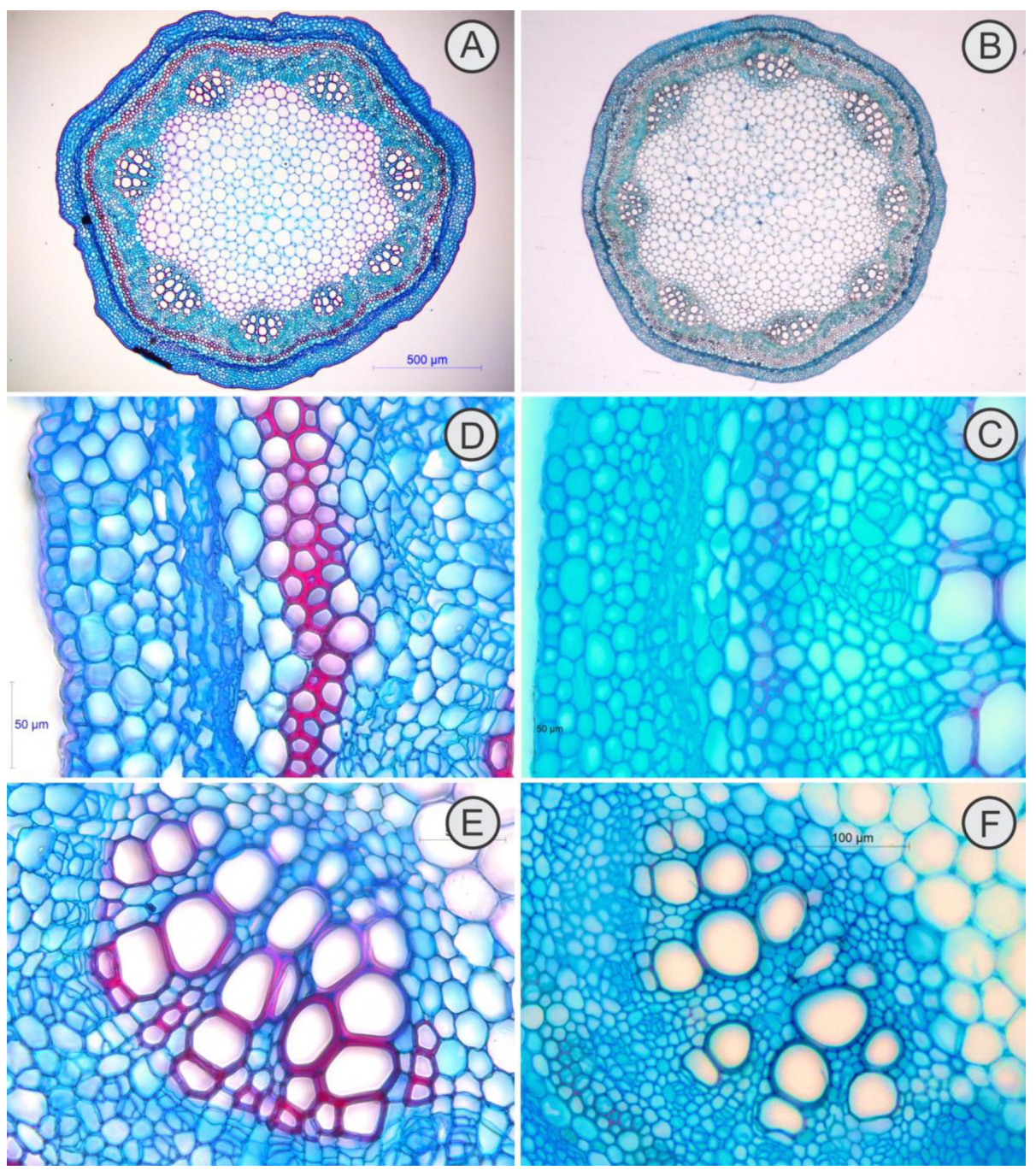

Figure 3. Petiole transverse cross-section. A. B. Overview, vascular bundle number, and arrangement. C. D. Details of epidermis, cortex, fibers, and gelatinous fibers. E. F. Details of shape and arrangement of phloem and secondary xylem. A. D. E. Manihot pohlii; B. C. F. M. caerulescens. 


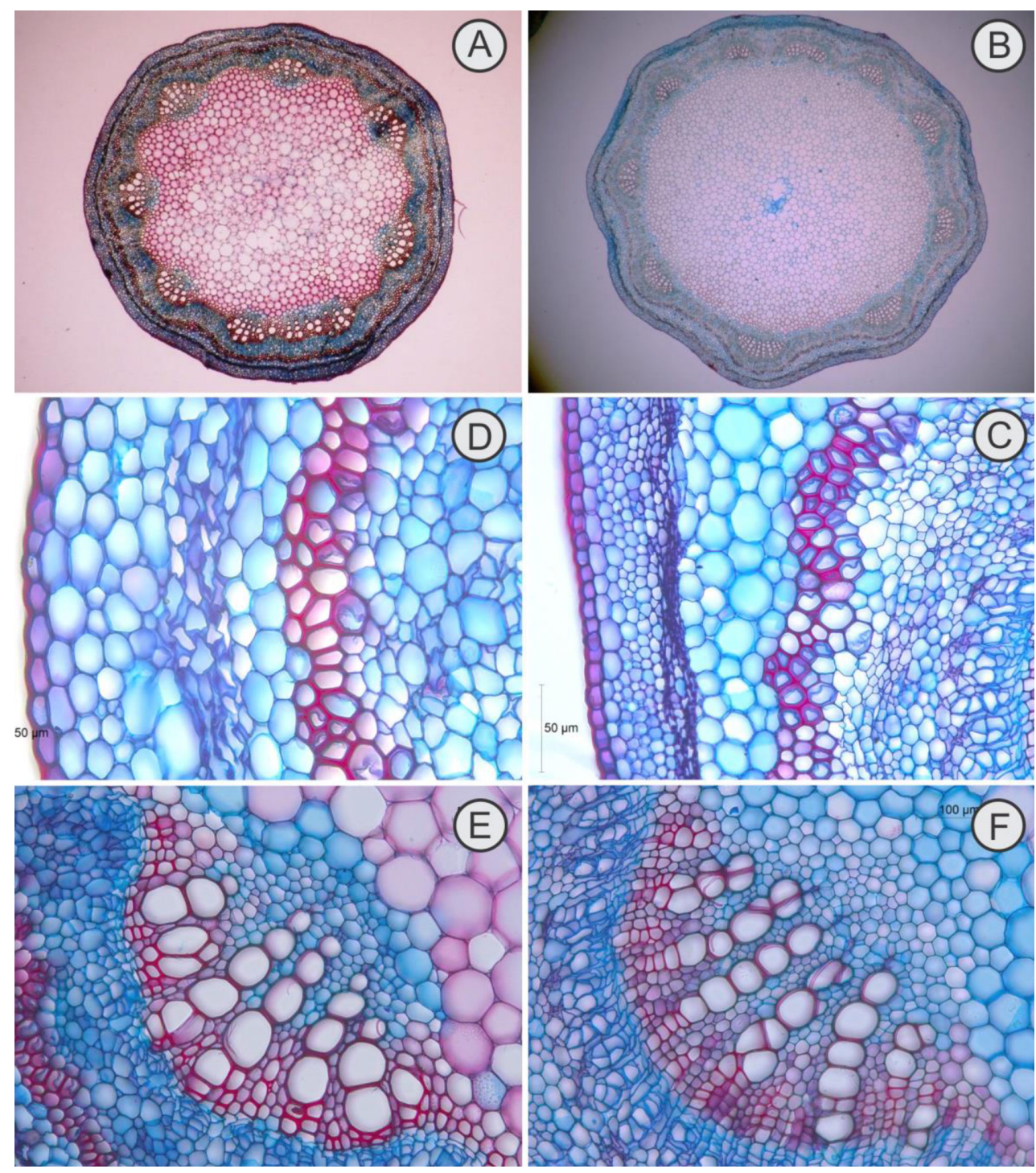

Figure 4. Petiole transverse cross-section. A. B. Overview, number, and arrangement of vascular bundles. C. D. Details of epidermis, cortex, and pericyclic fibers. E. F. Details of shape and arrangement of phloem and secondary xylem. A. D. E. Manihot esculenta var. 110; B. C. F. M. esculenta var. Branca Santa Catarina.

The starch sheath was mono-stratified, with varying cell quantity and type. In $M$. pseudoglaziovii, crystals and druses were frequent. In UNB 530 and M. glaziovii, druses were rare, but crystals were frequent. In UNB 110, both druses and crystals were rare, and in $M$. fortalezensis and Branca Santa Catarina, druses were rare and there were no crystals. Below the cortex, there were two to three layers of pericyclic fibers with thick walls that were submerged by a gelatinous fibers, except in Branca Santa Catarina. 


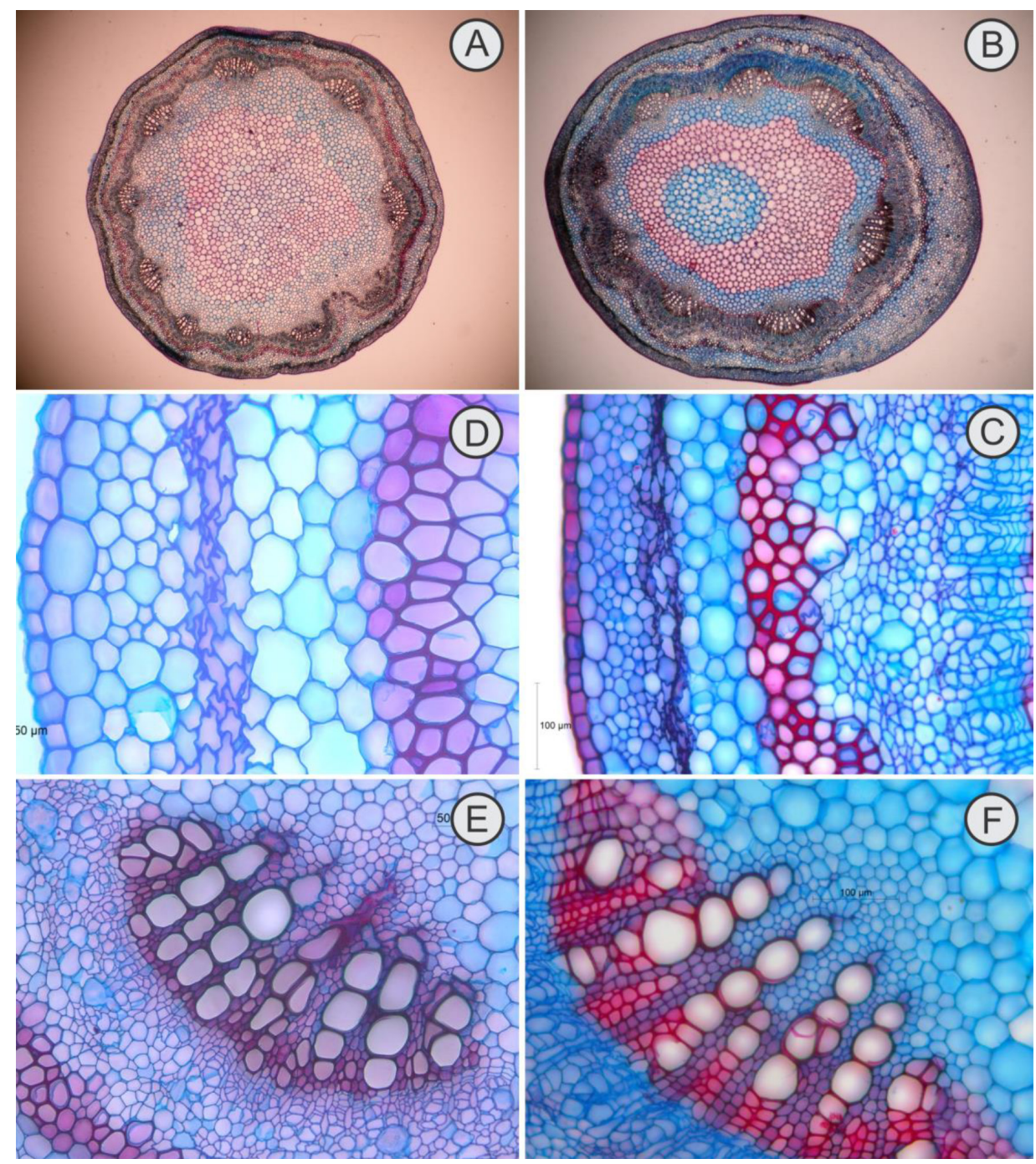

Figure 5. Petiole transverse cross-section. A. B. Overview, number, and arrangement of vascular bundles. C. D. Details of epidermis, cortex, and pericyclic fibers. E. F. Details of shape and arrangement of phloem and secondary xylem. A. D. E. Manihot esculenta; B. C. F. M. fortalezensis.

The vascular bundles were collateral (Figures $2 \mathrm{E}-\mathrm{F}, 3 \mathrm{E}-\mathrm{F}, 4 \mathrm{E}-\mathrm{F}$, and $5 \mathrm{E}-\mathrm{F}$ ) and organized in an interrupted cylindrical manner, with six in M. pohlii, seven in M. caerulescens and UNB 530, eight in Branca Santa Catarina, M. pseudoglaziovii, and UNB 110, and up to ten in M. fortalezensis and M. glaziovii. The external primary phloem was generally found collapsed in both regions (fascicular and inter-fascicular), and comprised sieve tube elements, companion cells, and laticifers; only in the rays of UNB 530 there were frequent crystals. The inter-fascicular cambium exhibited differentiation in the external parts only, with the secondary phloem highly developed, whereas the fascicular cambium was differentiated to both sides. 
Primary xylem persisted in all of the species, and vessel elements of secondary xylem with large diameters had several geminations surrounded by parenchyma. The number of rows ranged from 6 to 13. Laticifers were observed in the primary and secondary xylem.

The medulla was solid in all of the species, except in M. pseudoglaziovii and M. fortalezensis, in which it may have been fistulous. It was distinct, with peripheral and central parts. The peripheral cells were isodiametric with small intercellular spaces, whereas the cells in the central area were larger, ranging from isodiametric to polygonal, except in M. glaziovii, M. pohlii, and UNB 110, in which all of the cells were similar. A few crystals and druses occurred in $M$. fortalezensis, and they were frequent in $M$. glaziovii and $M$. caerulescens. Distinctive characteristics of the transverse sections, such as trichomes, lenticels, and stomata, were present in five species of Manihot (Figure 6A-F).

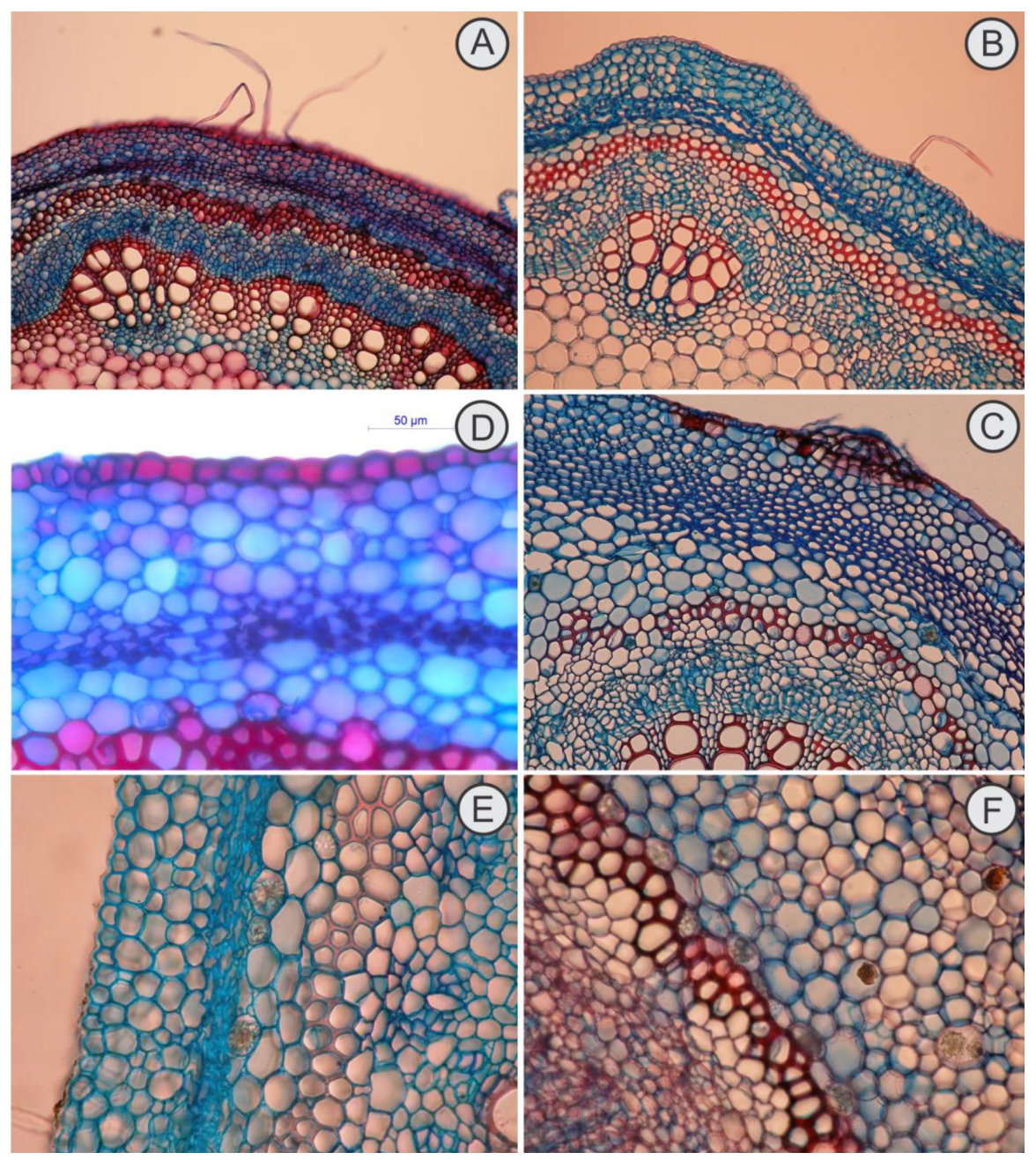

Figure 6. Main petiole anatomical differences. A. B. Trichomes. C. Lenticels. D. Stomata. E. F. Crystals (druses). A. Manihot esculenta var. 530; B. M. esculenta var. 110; C. E. M. esculenta Branca Santa Catarina; D. M. fortalezensis; and F. M. pseudoglaziovii. 
From the data obtained, it was possible to build the following identification key using the following characteristics: presence or absence of trichomes and a hypodermis, trichome format, the number of layers and vascular bundles, and the types of pith:

1. Presence of trichomes and petiole insertion

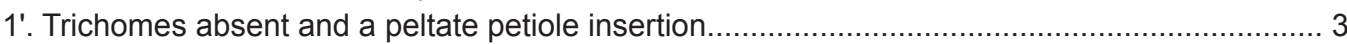

2. Broad trichomes, absence of a hypodermis, up to six vascular bundles.......... hybrid UNB 110

$2 '$. Narrow trichomes with tapered ends, presence of a hypodermis, frequent gelatinous fibers, and up to six vascular bundles M. pohlii

2". Trichomes with narrow tapered extremities, absence of a hypodermis, frequent gelatinous fibers, and up to seven vascular bundles. M. esculenta

2". Narrow trichomes with tapered ends, presence of a hypodermis, few gelatinous fibers, and up to eight vascular bundles. M. caerulescens 2"'. Trichomes narrow with tapered ends, absence of a hypodermis, frequent gelatinous fibers, and up to eight vascular bundles Branca Santa Catarina

3. No fistulous pith ...4

3'. Fistulous pith, presence of a hypodermis, frequent gelatinous fibers, and up to eight vascular bundles. M. pseudoglaziovii

3". Fistulous pith, presence of a hypodermis, frequent gelatinous fibers, and up to 10 vascular bundles

M. fortalezensis

4. Presence of a hypodermis, up to five discontinuous layers of collenchyma, few gelatinous fibers, and up to 10 vascular bundles M. glaziovii

We suggest that the petioles of Manihot species have the following anatomical characteristics: a uniseriate epidermis with anthocyanin; a cortex consisting of parenchyma and collenchyma; pericyclic fibers; a vascular system arranged in a cylindrical pattern; an ectophloic siphonostele; internal and external primary phloem; fascicular and inter-fascicular exchange; welldeveloped secondary phloem; and laticifers in phloematic tissue and pith. The petioles of the species studied were similar in terms of tissue type and arrangement to Manihot stems (Nassar et al., 2008; Graciano-Ribeiro et al., 2009). According to Esau (1974), the petioles of dicotyledones are often similar to their stems; our observations corroborate this.

\section{DISCUSSION}

Most Manihot species have long petioles, as noted by Rogers and Appan (1973) and Dehgan (1982), while in Jatropha species they range in size from 7 to $35 \mathrm{~cm}$. The petiole insertions of the different sections were as follows: peltate in Glaziovianae and basal in Manihot, Caerulescens, and Heterophyllae. Basal insertions also occur in Glaziovianae, but in the species studied, the insertions were peltate. The petioles and tissues containing the same location (arrangement) of those present in the stem of Manihot are described by Nassar et al. (2008) and Graciano-Ribeiro et al. (2009). According Esau (1974), the petiole of dicotyledons often has similar provision stem, and our observations corroborate this information. We observed trichomes in $M$. caerulescens, M. pohlii, the cultivars, and the hybrid. Trichomes, thick cuticles, and the presence of crystals and anthocyanins that were observed in this study are strongly related to minimizing water loss in dry environments (Fahn, 1986; Pallioti et al., 1994; Robinson and Osmond, 1994; Liakoura et 
al., 1999). The existence of trichomes in the cultivars, the hybrid, M. pohlii, and M. caerulescens appears to be directly related to the process of speciation, where natural selection favored the establishment of trichomes in low humidity environments. In other materials, the epidermis was entirely glabrous, as reported by Mendonça (1992). Anthocyanin was observed in epidermal cells in all specimens. This flavonoid is connected to photoinhibition and can accumulate on the stem in response to stress induced by cold or heat (Robinson and Osmond, 1994).

M. pseudoglaziovii, M. glaziovii, M. fortalezensis, and M. pohlii had a parenchymal layer similar to a hypodermis. The hypodermis plays an important role in drought resistance (Hameed et al., 2002), and probably functions as a water storage tissue in such species. These anatomical changes may occur in plants as an adaptation to drought stress (Makbul et al., 2011).

We observed a continuous layer of collenchyma (which is involved in mechanical support) of variable thickness below the chlorenchyma in the cortex. The same was found in M. glaziovii by Mendonça (1992), in Alchornea triplinervia (Spreng.) Müll.Arg. (Euphorbiaceae) by Rôças et al. (1997), and in Polymorphae Pax, Jatropha genus (Dehgan, 1982). Pericyclic fibers in the cortex form two to three continuous layers. Makbul et al. (2011) noted that in plants under drought stress, the fibers have the same distribution, and the number of layers increases. According to these authors, sclerenchyma prevents water loss, which would explain the adaptability of species in tropical regions, such as Manihot, to drought stress. Güvenç and Duman (2010) reported that ecological factors can affect anatomical characteristics, including the distribution of supporting tissue.

In most materials in the fiber region, we observed pericyclic fibers with little lignified walls that were stained blue; these cells have characteristics that allow their classification as gelatinous fibers, similar to those defined by Tomlinson (2003). These were observed in the stems of a cultivar (UNB 99), a hybrid (UNB 110), and M. glaziovii by Nassar et al. (2010b), and may be involved in retaining water and conferring greater resistance to drought. Gelatinous fibers around the vascular cylinder were also observed by Sá-Haiad et al. (2009) in the Crotoneae tribe (Euphorbiaceae). Gelatinous fibers have also been reported in the underground systems of Cerrado plants (Paviani, 1978), and the presence of cellulose (which is hydrophilic and considered xeromorphic) may be related to water storage. The species we studied were from arid zones, so we also consider the presence of these fibers as a xeromorphic feature.

Laticifers were observed in the cortex, phloematic tissue, xylem, and on the periphery of the pith, and is a common characteristic of the Euphorbiaceae (Metcalfe and Chalk, 1950). Nassar et al. (2008) reported the occurrence of laticifers in Manihot stems only in the cortex and primary and secondary phloems, differing from our findings. The vascular system of the petiole is cylindrical and is interrupted by the phloem around the xylem, and has been described in $M$. glaziovii (Mendonça, 1992) and other species of the Euphorbiaceae (Hussin et al., 1996).

The number of vascular bundles in the petiole was variable; according to Dehgan (1982), a reduction in a number of Jatropha traits followed its evolutionary advancement, and the reduction in bundles corresponds to an adaptation to the arid climates of Central America and Africa. When investigating the petioles of Jatropha maheshwarii Subr. \& M.P. Nayar, Uthayakumari and Sumathy (2011) also found infrageneric relationships related to the number of vascular bundles, and considered the reduction evolutionarily recent.

Among the wild species studied, there was also variation in the number of vascular bundles in the petiole, and M. fortalezensis and M. glaziovii had the greatest number of vascular bundles and the longest petioles, which reflected their large external morphology. Pitman et al. (1983) and Guerfel et al. (2009) observed that tissues exposed to environments with little water 
generally exhibit increased vascular structure; these two species are indigenous to northeastern Brazil, a region with little water and bright sunshine. The number of vascular bundles and rows of vessel elements, and petiole length, tended to be lower in the hybrid. This was also reported by Ristic and Cass (1991), who only found a small area of vascular tissue. The hybrid, formed by the genes of wild and domesticated species, acted quantitatively in relation to the overall size of the petiole, revealing a heterozygous combination already in the parents. These features in the hybrid petiole may be a response to drought stress (Kutlu et al., 2009). The medullary parenchyma has thin walls with small or few intercellular spaces, which is consistent with that seen in M. glaziovii by Mendonça (1992), but differs from the results of Sá-Haiad et al. (2009), who found that in the Crotoneae the parenchyma cells have thick walls. The occurrence of two cell types in some tissues agrees with stem data (Nassar et al., 2008).

From the anatomical characters of the parents (M. esculenta and M. glaziovii), the hybrid UNB 110 shows greater number of characters from $M$. esculenta, such as petiole insertion type, thick cuticle, presence of trichomes, absence of hypoderm, rare druses and crystals. The vascular system is also more related to M. esculenta. In Salvia, it is also possible to differentiate the genitors of the hybrid due to aspects found on sectioned leaves and some epidermic characters (Dickison 2000). Thus, these hybrids show evidence of morpho-anatomical characteristics of their parents, which could be used not only to link the relationship and similarity among hybrid and parents, but also to taxonomically differentiate them.

Taking into consideration the process of natural selection (related to the species initially with no economic value imputed, i.e., those whose anthropic interaction is minimal or nonexistent - M. pohlii and M. caerulescens), it is possible to consider that the qualitative characters are a result of the expression of genes that made the population more adapted to the environment. Thus, the correlation between anatomical and physiological characters is robust. In the other species that suffered some level of domestication, the qualitative characters can also occur due to natural selection, even though it is not as strongly evident as in M. pohlii and M. caerulescens. The weak selective pressure could explain the presence of these species in places where they are not expected, when considering the anatomical characteristics related to the environment. Even though it may not be applied to the appearance of these anatomical characters, the maintenance of such characters throughout the years might be guided by an environmental factor, since these species are present in the same location for a long time (there are exsiccatae dated from around 1900). Some characteristics we observed may be related to drought resistance, such as the presence of trichomes, a hypodermis, gelatinous fibers, crystals, druses, and the number of cell layers and vascular bundles. Such anatomical data are useful for cassava improvement. The selection pressure that was exerted naturally in wild species established the morphological and anatomical patterns observed in $M$. pohlii and $M$. caerulescens. The domestication process promoted the selection of short petioles; the hybrid is a morphological and anatomical intermediary, and highlights the heterozygous nature of parents. In summary, an arid environment resulted in quantitative changes (the number of layers and vascular bundles) and, above all, qualitative changes, such as the presence of trichomes, which allows the use of these characteristics as taxonomic tools for species identification in this genus.

\section{REFERENCES}

Berlyn GP and Miksche JP (1976). Botanical microtechnique and cytochemistry. lowa State University Press, Ames. 
Bomfim NN, Graciano-Ribeiro D and Nassar NMA (2011a). Genetic diversity of root anatomy in wild and cultivated Manihot species. Genet. Mol. Res. 10: 544-551.http://dx.doi.org/10.4238/vol10-2gmr1093

Bomfim NN, Ribeiro DG and Nassar NMA (2011b). Anatomic changes due to interspecific grafting in cassava (Manihot esculenta). Genet. Mol. Res. 10: 1011-1021.http://dx.doi.org/10.4238/vol10-2gmr1138

Dehgan B (1982). Comparative anatomy of the petiole and infrageneric relationships in Jatropha (Euphorbiaceae). Am. J. Bot. 69: 1283-1295. http://dx.doi.org/10.2307/2442753

Dickinson WC (2000). Integrative plant anatomy. Harcourt Academic Press, San Diego.

Esau K (1974). Anatomia das plantas com sementes. EDUSP, Edgard Blücher. São Paulo.

Fahn A (1986). Structural and functional properties of trichomes of xeromorphic leaves. Ann. Bot. (Lond.) 57: 631-637.

França AA, Guim A, Batista AMV, Pimentel RMM, et al. (2010). Anatomia e cinética de degradação do feno de Manihot glaziovii. Acta Sci. Anim. Sci 32: 131-138. http://dx.doi.org/10.4025/actascianimsci.v32i2.8800

Graciano-Ribeiro D, Hashimoto DYC, Nogueira LC, Teodoro D, et al. (2009). Internal phloem in an interspecific hybrid of cassava, an indicator of breeding value for drought resistance. Genet. Mol. Res. 8: 1139-1146. http://dx.doi.org/10.4238/vol8-3gmr629

Guerfel M, Baccouri O, Boujnah D, Chaibi W, et al. (2009). Impacts of water stress on gas exchange, water relations, chlorophyll content and leaf structure in the two main Tunisian olive (Olea europaea L.) cultivars. Sci. Hortic. (Amsterdam) 119: 257263. http://dx.doi.org/10.1016/j.scienta.2008.08.006

Güvenç A and Duman H (2010). Morphological and anatomical studies of annual species of Sideritis L. (Lamiaceae), with notes on chorology in Turkey. Turk. J. Bot. 34: 83-104.

Hameed M, Mansoor U, Ashraf UM and Rao A (2002). Variation in leaf anatomy in wheat germplasm from varying drought-hit habitats. Int. J. Agric. Biol. 4: 12-16.

Hashimoto-Freitas DY and Nassar NMA (2013). Cytogenetic and anatomic behavior of cytochimeras and total polyploids in cassava. Genet. Mol. Res. 12: 4879-4894.http://dx.doi.org/10.4238/2013.October.22.7

Hussin KH, Wahab BA and Teh CP (1996). Comparative leaf anatomical studies of some Mallotus Lour. (Euphorbiaceae) species. Bot. J. Linn. Soc. 122: 137: 153.

Johansen DA (1940). Plant microtechnique. McGraw-Hill, New York.

Kraus JE and Arduin M (1997). Manual básico de métodos em morfologia vegetal. Editora da Universidade Rural, Rio de Janeiro.

Kutlu N, Terzi R, Tekeli C, Senel G, et al. (2009). Changes in anatomical structure and levels of endogenous phytohormones during leaf rolling in Ctenanthe setosa. Turk. J. Biol. 33: 115-122.

Liakoura V, Stavrianakou S, Liakopoulos G, Karabourniotis G, et al. (1999). Effects of UV-B radiation on Olea europaea: comparisons between a greenhouse and a field experiment. Tree Physiol. 19: 905-908. http://dx.doi.org/10.1093/treephys/19.13.905

Luque R, Sousa HC and Kraus JE (1996). Métodos de coloração de Roeser (1972) - modificado- e Kropp (1972) visando a substituição do azul de astra por azul de alciao 8GS ou 8 GX. Acta Bot. Brasilica 10: 199-212.

Makbul S, Nsaruhan Güler N, Durmuş N and Güve S (2011). Changes in anatomical and physiological parameters of soybean under drought stress. Turk. J. Bot. 35: 369-37.

Mendonça MS (1992). Estudo de plantas laticíferas. II: Aspectos anatômicos e distribuição de vasos laticíferos em Manihot glaziovii Müller Arg. Acta Amazon. 22: 309-321. http://dx.doi.org/10.1590/1809-43921992223321

Metcalfe CR and Chalk L (1950). Anatomy of the dicotyledons, volume II. Clarendon Press, Oxford.

Nassar NMA (2002). Cassava, Manihot esculenta Crantz, genetic resources: origin of the crop, its evolution and relationships with wild relatives. Genet. Mol. Res. 1: 298-305

Nassar NMA, Graciano-Ribeiro D, Fernandes SDC and Araujo PC (2008). Anatomical alterations due to polyploidy in cassava, Manihot esculenta Crantz. Genet. Mol. Res. 7: 276-283.http://dx.doi.org/10.4238/vol7-2gmr399

Nassar NMA, Graciano-Ribeiro D, Gomes PF and Hashimoto DYC (2010a). Alterations of reproduction system in a polyploidized cassava interspecific hybrid. Hereditas 147: 58-61.http://dx.doi.org/10.1111/j.1601-5223.2009.02150.x

Nassar NMA, Abreu LFA, Teodoro DAP and Graciano-Ribeiro D (2010b). Drought tolerant stem anatomy characteristics in Manihot esculenta (Euphorbiaceae) and a wild relative. Genet. Mol. Res. 9: 1023-1031. http://dx.doi.org/10.4238/vol9-2gmr800

Nassar NMA, Hashimoto DYC and Ribeiro DG (2010c). Genetic, embryonic and anatomical study of an interspecific cassava hybrid. Genet. Mol. Res. 9: 532-538. http://dx.doi.org/10.4238/vol9-1gmr746

Nassar NMA, Graciano-Ribeiro D, Bomfim NN and Gomes PTC (2011). Manihot fortalezensis Nassar, Ribeiro, Bomfim et Gomes a new species of Manihot from Ceará, Brazil. Genet. Resour. Crop Evol. 58 (6): 831-835.

Paiva JGA, Fank-De-Carvalho SM, Magalhaes MP and Graciano-Ribeiro D (2006). Verniz vitral incolor 500 ${ }^{\circledR}$ : a mounting medium alternative and economically viable. Acta Bot. Brasilica 20: 257-264. http://dx.doi.org/10.1590/S0102-33062006000200002 
Pallioti A, Bongi G and Rocchi P (1994). Peltate trichomes effects on photosynthetic gas exchange of Olea europaea L. leaves. Plant Physiol. 13: 35-44.

Paviani TI (1978). Anatomia vegetal e cerrado. Cienc. Cult. 30: 1076-1086.

Pitman WD, Holte C, Conrad BE and Bashaw EC (1983). Histological differences in moisture stressed and non-stressed Klein grass forage. Crop Sci. 23: 793-795. http://dx.doi.org/10.2135/cropsci1983.0011183X002300040046x

Ristic Z and Cass DD (1991). Leaf anatomy of Zea mays L. in response to water shortage and high temperature: a comparison of drought-resistant and drought-sensitive lines. Bot. Gaz. 152: 173-185. http://dx.doi.org/10.1086/337877

Robinson SA and Osmond CB (1994). Internal gradients of chlorophyll and carotenoid pigments in relation to photoprotection in thick leaves of plants with crassulacean acid metabolism. Funct. Plant Biol. 21: 497-506.

Rôças G, Barros CF and Scarano FR (1997). Leaf anatomy plasticity of Alchornea triplinervia (Euphorbiaceae) under distinct light regimes in a Brazilian montane Atlantic rain forest. Trees (Berl.) 11: 469-473. http://dx.doi.org/10.1007/PL00009688

Rogers DJ and Appan SG (1973). Manihot and Manihotoides (Euphorbiaceae). A computer-assisted study. Organization for Flora Neotropica (ed.), Flora Neotropica Monograph 13. Hafner Press, New York.

Sá-Haiad B, Serpa-Ribeiro ACC, Barbosa CN, Pizzini D, et al. (2009). Leaf structure of species from three closely related genera from tribe Crotoneae Dumort. (Euphorbiaceae s.s. Malpighiales). Plant Syst. Evol. 283: 179-202. http://dx.doi.org/10.1007/s00606-009-0229-x

Tomlinson PB (2003). Development of gelatinous (reaction) fibers in stems of Gnetum gnemon (Gnetales). Am. J. Bot. 90: 965-972. http://dx.doi.org/10.3732/ajb.90.7.965 PubMed

Uthayakumari F and Sumathy M (2011). Pharmacognostical studies on the endemic medicinal plant- Jatropha maheswarii Subr. \& Nayar (Euphorbiaceae). Int. J. Pharm. Tech. Res. 3: 2169-2174. 